\title{
Analisis Hukum Penetapan Tersangka dalam Kasus Pungutan Liar (Pungli) sebagai Tindak Pidana Korupsi
}

\author{
Legal Analysis of The Determination of Suspects with Illegal Levies \\ (Extortion) As A Criminal Act of Corruption
}

\author{
Darwin Panjaitan \\ Hakim Ad Hoc Tipikor Pengadilan Negeri Kendari \\ E-mail: darwin.panjaitan.sh@gmail.com \\ Herman \\ Pascasarjana Universitas Halu Oleo \\ E-mail: man.herman76@yahoo.com \\ Oheo K. Haris \\ Pascarjana Universitas Halu Oleo \\ E-Mail: oheokh@gmail.com
}

\begin{abstract}
The witness as the giver of money in the case of illegal levies (extortion) as a Corruption Crime as formulated in Article 12 letter (e) of the Republic of Indonesia's Constitution Number 20 of 2001 on Amendments to the Law of the Republic of Indonesia Number 31 of 1999 concerning Eradication of Corruption Crimes cannot be legally determined be a suspect giving bribes or gifts. This is because the witness as the party who gave money to the suspect (extortion agent) did not have any initiative or malice (mens rea) but because he was forced to. Where the suspect extortion is in a more dominant position by using the position or power he has. In the trial of Public Prosecutors often unable to prove the element of "force" as stipulated in Article 12 letter (e), so in the letter of prosecution the Public Prosecutor ensnares the Suspect / Defendant using Article 11 of the Republic of Indonesia Law Number 20 of 2001 on Amendments to the Law RI Number 31 of 1999 Concerning Eradication of Corruption. Though both of these crimes are 2 (two) different things.
\end{abstract}

Keyword: Determination of Suspects, Extortion; Forcing; Corruption

Abstrak: Saksi selaku pemberi uang dalam kasus Pungutan Liar (Pungli) sebagai Tindak Pidana Korupsi sebagaimana dirumuskan dalam Pasal 12 huruf (e) Undang-Undang Republik Indonesia Nomor 20 Tahun 2001 Atas Perubahan Undang-Undang Republik Indonesia Nomor 31 Tahun 1999 Tentang Pemberantasan Tindak Pidana Korupsi secara hukum tidak dapat ditetapkan menjadi Tersangka memberi suap atau hadiah, karena Saksi selaku pihakyang memberikan uang kepada Tersangka (pelaku pungli) sama sekali tidak punya inisiatif atau niat jahat (mens rea) melainkan karena terpaksa, dimana Tersangka pelaku pungli berada dalam posisi lebih dominan dengan menggunakan kedudukan atau kekuasaan yang ada padanya. Dalam persidangan Penuntut Umum 
sering kali tidak mampu membuktikan unsur "memaksa" sebagaimana ditentukan dalam Pasal 12 huruf (e) tersebut, sehingga dalam surat tuntutannya Penuntut Umum menjerat Tersangka/Terdakwa dengan menggunakan Pasal 11 Undang-Undang Republik Indonesia Nomor 20 Tahun 2001 Atas Perubahan Undang-Undang Republik Indonesia Nomor 31 Tahun 1999 Tentang Pemberantasan Tindak Pidana Korupsi. Padahal kedua tindak pidana tersebut merupakan 2 (dua) hal yang berbeda.

Kata kunci: Penetapan Tersangka; Pungli; Memaksa, Tipikor

\section{PENDAHULUAN}

Pungutan liar atau biasa disingkat pungli dapat diartikan sebagai pungutan yang dilakukan oleh dan untuk kepentingan pribadi oknum petugas secara tidak sah atau melanggar aturan. Pungutan liar merupakan salah satu bentuk penyalahgunaan wewenang yang memiliki tujuan untuk memudahkan urusan atau memenuhi kepentingan dari pihak pembayar pungutan. Sehingga dapat disimpulkan bahwa pungutan liar melibatkan dua pihak atau lebih, baik itu pengguna jasa ataupun oknum petugas yang biasa melakukan kontak langsung untuk melakukan transaksi rahasia maupun terang-terangan, dimana pada umumnya pungutan liar atau pungli yang terjadi pada tingkat lapangan dilakukan secara singkat dan biasanya berupa uang1.

Pungutan liar yang biasa disingkat dengan pungli dalam praktik penegakan hukum bukanlah hal baru, namun secara tertulis dalam regulasi dan bahkan dalam literatur-literatur pun yang membahas tentang pungli sebagai bentuk tindak pidana korupsi hampir tidak ada. Penegakan hukum terhadap para pelaku tindak pidana korupsi oleh institusi penegak hukum seperti Kepolisian, Kejaksaan dan KPK, sebagaimana diatur di dalam Undang-Undang Republik Indonesia Nomor 8 Tahun 1981 tentang Kitab Undang-Undang Hukum Acara Pidana (KUHAP) menganut konsep diferensiasi fungsional di antara komponen penegak hukum yang melaksanakan fungsi kekuasaan kehakiman dan penegakan hukum pada umumnya. Konsep diferensiasi fungsional yang dianut KUHAP sebagaimana tercermin dari pembagian fungsi dan kewenangan aparat penegak hukum dalam tugas-tugas:

1. Penyelidikan dan penyidikan.

2. Penuntutan.

3. Pemeriksaan disidang Pengadilan, dan

4. Pelaksanaan putusan hakim. ${ }^{2}$

1 Samodra Wibawa, Arya Fauzy F.M, dan Ainun Habibah, "Efektivitas Pengawasan Pungutan Liar Di Jembatan Timbang,". Jurnal Ilmu Administrasi Negara, Vol 12 No 2, Januari 2013, hlm. 75.

2 M. Yahya Harahap, Pembahasan, Permasalahan dan Penerapan KUHAP, Jakarta: Pustaka Kartini, 1993, hlm. 45-46. 
Perkembangan teknologi dan informasi sebagai dampak globalisasi pada masa kini membawa pengaruh yang sangat besar pada kehidupan dan peradaban manusia. Kemajuan yang telah membawa pengaruh besar dan berdampak pada tindakan Pemerintah untuk membuat regulasi-regulasi baru khususnya pada upaya penanggulangan kasus pungutan liar yang nyata-nyata merupakan tindak pidana korupsi yaitu dengan terbitnya Peraturan Presiden Republik Indonesia Nomor 87 Tahun 2016 Tentang Satuan Tugas Sapu Bersih Pungutan Liar yang sering dijadikan sebagai modus operandi oleh para pelaku tindak pidana korupsi, memang harus diakui bahwa jauh sebelum itu telah banyak regulasi-regulasi yang dihasilkan oleh pemerintah bersama-sama dengan DPR sebagai lembaga legislatif. Salah satu produk hukumnya adalah lahirnya Undang-Undang Republik Indonesia Nomor 31 Tahun 1999 tentang Pemberantasan Tindak Pidana Korupsi sebagaimana telah diubah dan ditambah dengan Undang-Undang Republik Indonesia Nomor 20 Tahun 2001 Tentang Perubahan atas UndangUndang Republik Indonesia Nomor 31 Tahun 1999 Tentang Pemberantasan Tindak Pidana Korupsi.

Pungutan liar (pungli) sebagai Tindak Pidana Korupsi tersebut sesungguhnya masuk dalam kualifikasi Tindak Pidana Korupsi sebagaimana diatur dalam ketentuan Pasal 12 huruf (e) Undang-Undang Republik Indonesia Nomor 31 Tahun 1999 Tentang Pemberantasan Tindak Pidana Korupsi sebagaimana telah diubah dan ditambah dengan Undang-Undang Republik Indonesia Nomor 20 Tahun 2001 yang berbunyi sebagai berikut:

Dipidana dengan pidana penjara seumur hidup atau pidana penjara paling singkat 4 (empat) tahun dan paling lama 20 (dua puluh) tahun dan pidana denda paling sedikit Rp. 200.000.000.- (dua ratus juta rupiah) dan paling banyak Rp. 1.000.000.000.- (satu milyar rupiah):

e. Pegawai Negeri atau Penyelenggara Negara yang dengan maksud menguntungkan diri sendiri atau orang lain secara melawan hukum, atau dengan menyalahgunakan kekuasaannya memaksa seseorang memberikan sesuatu, membayar, atau menerima pembayaran dengan potongan, atau untuk mengerjakan sesuatu bagi dirinya sendiri.

Dalam persidangan, Penuntut Umum sering kali tidak mampu membuktikan unsur "memaksa" seseorang memberikan sesuatu, membayar, atau menerima pembayaran dengan potongan, atau untuk mengerjakan sesuatu bagi dirinya yang merupakan salah satu unsur dari Pasal 12 huruf (e) Undang-Undang Republik Indonesia Nomor 31 Tahun 1999 Tentang Pemberantasan Tindak Pidana Korupsi sebagaimana telah diubah dan ditambah dengan Undang-Undang Republik Indonesia Nomor 20 Tahun 2001, sehingga untuk mengantisipasi 
putusan bebas (vrijsprak) sebagaimana Pasal 191 ayat (1) KUHAP atau putusan lepas (onslag van recht vervolging) sebagaimana Pasal 191 ayat (2) KUHAP, maka Penuntut Umum selalu melapis dakwaannya dengan Pasal 11 Undang-Undang Republik Indonesia Nomor 31 Tahun 1999 sebagaimana telah diubah dengan Undang-Undang Republik Indonesia Nomor 20 Tahun 2001 yang selanjutnya disebut dakwaan alternatif kedua atau dakwaan subsider.

Berdasarkan uraian singkat di atas maka rumusan masalah dalam tulisan ini adalah apakah saksi selaku pemberi uang dalam kasus Pungutan Liar (Pungli) sebagai Tindak Pidana Korupsi dapat ditetapkan menjadi Tersangka? Kemudian, apakah Pelaku Pungutan Liar (Pungli) Sebagai Tindak Pidana Korupsi Dapat Dituntut Melanggar Pasal 11 Undang-Undang Republik Indonesia Nomor 20 Tahun 2001 Atas Perubahan Undang-Undang Republik Indonesia Nomor 31 Tahun 1999 Tentang Pemberantasan Tindak Pidana Korupsi?

\section{METODE PENELITIAN}

Penelitian ini adalah penelitian hukum (legal research) yakni mencari dan menemukan kebenaran koherensi, di dasarkan pada kesesuaian antara yang ditelaah dengan aturan yang ditetapkan. Peter Mahmud Marzuki mengatakan Penelitian hukum adalah suatu Proses untuk menentukan antara hukum, Prinsip-prinsip hukum, maupun Doktrin-doktrin hukum guna menjawab isu hukum yang dihadapi. ${ }^{3}$

\section{ANALISIS DAN PEMBAHASAN}

Penetapan Tersangka Terhadap Saksi Selaku Pemberi Uang Dalam Kasus Pungutan Liar (Pungli) Sebagai Tindak Pidana Korupsi

Beranjak dari rumusan Pasal 12 huruf (e) (f) dan (g) Undang-Undang Republik Indonesia Nomor 20 Tahun 2001 atas Perubahan Undang-Undang Republik Indonesia Nomor 31 Tahun 1999 Tentang Pemberantasan Tindak Pidana Korupsi, maka salah satu syarat yang sangat krusial dalam perbuatan pungutan liar (pungli) adalah harus ada sifat atau unsur "memaksa" yang menjadi karakter khusus dalam pungutan liar (pungli) sebagai Tindak Pidana Korupsi, dimana selain unsur memaksa tentunya juga masih ada unsur-unsur yang lain.

"Memaksa" artinya melakukan tekanan pada orang, sehingga orang itu melakukan sesuatu yang berlawanan dengan kehendak sendiri . Memaksa dalam hal ini haruslah juga

3 Peter Mahmud Marzuki, Penelitian Hukum Edisi Revisi, Cet. VII, Jakarta: Prenada Media Group, 2011, hlm. 47.

4 R. Soesilo, Pokok-Pokok Hukum Pidana Peraturan Umum dan Delik-delik Khusus, Bogor: Politea, 1984, hlm.139-140. 
dimaknai sebagai "melawan hak" atau sama dengan melawan hukum atau tidak berhak atau bertentangan dengan hukum.

Dengan terpenuhinya unsur "memaksa" telah membuktikan adanya mens rea atau niat jahat dari si pelaku. Salah satu tolok ukur untuk menilai niat jahat pelaku dapat di hubungkan dengan teori kesengajaan atau Willen en Weten. Menurut Sathochid Kartanegara, yang dimaksud dengan opzet willen en weten (dikehendaki dan diketahui) adalah "Seseorang yang melakukan suatu perbuatan dengan sengaja harus menghendaki (willen) perbuatan itu serta harus menginsafi atau mengerti (weten) akan akibat dari perbuatan itu"; "Kehendak" dapat ditujukan terhadap:

a. Perbuatan yang dilarang; dan

b. Akibat yang dilarang. ${ }^{5}$

Kata memaksa dalam rumusan pungutan liar tidak bisa dipisahkan dengan kalimat yang ada di belakangnya yang selengkapnya berbunyi "memaksa orang untuk memberikan sesuatu, membayar atau menerima pembayaran dengan potongan atau dengan mengerjakan sesuatu bagi dirinya sendiri".

Sebelum menjawab rumusan masalah 1 (satu) di atas yaitu: "Apakah Saksi selaku pemberi uang dalam kasus Pungutan Liar (Pungli) sebagai Tindak Pidana Korupsi dapat ditetapkan menjadi Tersangka?” Maka perlu kiranya terlebih dahulu menguraikan definisi Saksi.

Undang-Undang Republik Indonesia Nomor 8 Tahun 1981 Tentang Hukum Acara Pidana (KUHAP) Pasal 1 angka 26 menyatakan: Saksi adalah orang yang dapat memberikan keterangan guna kepentingan penyidikan, penuntutan dan peradilan tentang suatu perkara pidana yang ia dengar sendiri, ia alami sendiri.

Lebih lanjut Pasal 185 ayat (1) KUHAP yang berbunyi: "Keterangan saksi sebagai alat bukti ialah apa yang saksi nyatakan di sidang pengadilan". Jika keterangan saksi di sidang berbeda dengan keterangannya yang terdapat dalam Berita Acara, Hakim ketua sidang mengingatkan saksi tentang hal itu serta minta keterangan mengenai perbedaan yang ada dan dicatat dalam berita acara pemeriksaan sidang (Pasal 163 KUHAP).

Senada dengan penjelasan di atas, yang dimaksud sebagai Saksi dalam tulisan ini adalah "Saksi Selaku Pemberi Uang” dalam Kasus Pungutan Liar (Pungli) Sebagai Tindak Pidana Korupsi sebagaimana dirumuskan dalam Pasal 12 huruf (e) Undang-Undang Republik

5 Satochid Kartanegara, Hukum Pidana Bagian Satu, Jakarta: Balai Lektur Mahasiswa, 2007, hlm. 184-186. 
Indonesia Nomor 20 Tahun 2001 Atas Perubahan Undang-Undang Republik Indonesia Nomor 31 Tahun 1999 Tentang Pemberantasan Tindak Pidana Korupsi, jadi dalam transaksi pungutan liar tersebut terdapat 2 (dua) pihak yaitu "pemberi uang dan penerima uang".

Undang-Undang Republik Indonesia Nomor 31 Tahun 1999 Tentang Pemberantasan Tindak Pidana Korupsi sebagaimana telah diubah dengan Undang-Undang Republik Indonesia Nomor 20 Tahun 2001 Tentang Perubahan atas Undang-Undang Republik Indonesia Nomor 31 Tahun 1999 Tentang Pemberantasan Tindak Pidana Korupsi tidak memberikan pengertian yang tegas tentang apa yang dimaksud dengan "pemberi uang" atau "memberi sesuatu" atau "memberi hadiah". Bahkan, pembuat undang-undang sendiri tidak menjelaskan makna "memberi sesuatu" yang tercantum dalam Pasal 5 ayat (1) huruf a, b, Pasal 5 ayat (2), Pasal 6 ayat (1) huruf a, b, Pasal 6 ayat (2), Pasal 11, Pasal 12 huruf a, b, c, d hingga Pasal 13, namun hanya disebutkan di dalam penjelasan pasalnya dinyatakan "cukup jelas". Hal tersebut dapat dimengerti karena perbuatan "memberi" atau "menjanjikan" merupakan perbuatan yang sudah umum dan dapat dipahami maksudnya oleh seluruh masyarakat yang menggunakan Bahasa Indonesia.

Namun demikian, apabila perbuatan "memberi sesuatu" atau "memberi hadiah" dikaitkan dengan pengertian yuridis maka seyogyanya perlu mencari tahu makna yuridis yang terkandung dalam kata memberi sesuatu tersebut. Dalam hal undang-undang tidak memberi penjelasan, maka sesuai dengan prinsip hukum acara pidana, dapat ditelusuri makna yuridis tersebut melalui sumber hukum yang dianut dalam sistem peradilan Indonesia, antara lain melalui pendapat ahli hukum (doctrin) ataupun yurisprudensi.

Menurut Adami Chazawi ${ }^{6}$, Unsur memberikan atau menjanjikan sesuatu adalah "Sesuatu yang diberikan atau dijanjikan merupakan obyek tindak pidana ini. Sesuatu itu tidak harus berupa benda (berwujud), akan tetapi boleh segala sesuatu yang tidak berwujud, misalnya pekerjaan, fasilitas, bahkan jasa; yang penting sesuatu itu bernilai atau berharga (terutama dari segi ekonomi), berguna, bermanfaat, atau segala sesuatu yang menyenangkan bagi penerima. Logikanya ialah dengan segala sesuatu yang bernilai dan berguna atau menyenangkan si penerima itulah yang dapat memenuhi apa yang dituju (dimaksudkan) oleh si pembuat, yakni pegawai negeri yang menerima pemberian yakni berbuat sesuatu atau tidak berbuat sesuatu yang disadarinya bertentangan dengan kewajiban jabatannya.

6 Adami Chazawi, Hukum Pidana Materiil dan Formil di Indonesia, Edisi Pertama, Cetakan Kedua, Malang: Bayu Media Publishing, 2005, hlm. 58-59. 
Dengan demikian, jika ditarik kesimpulan dari pendapat di atas dalam hal ini pendapat dari Adami Chazawi tersebut, maka pemberian atau memberikan sesuatu tergolong tindak pidana suap menyuap, namun konteksnya masih terlalu abstrak. Kalau demikian muncul lagi pertanyaan suap itu sebenarnya apa? Karena tidak adanya literatur yang secara eksplisit memberikan definisi tentang suap, sehingga penulis lebih menggunakan pendekatan formal dan akan memberikan esensi suap itu memberi sesuatu untuk berharap sesuatu, suap itu harus ada deal kesepakatan antara dua pihak termasuk kesepakatan jumlah yang diperjanjikan, tetapi kalau kemudian posisinya salah satu lebih dominan dan yang lain tidak seimbang maka inilah yang disebut "Pungutan Liar (Pungli) atau pemerasan" sebagaimana ditentukan dalam Pasal 12 huruf (e) (f) dan (g) Undang-Undang Republik Indonesia Nomor 20 Tahun 2001 Atas Perubahan Undang-Undang Republik Indonesia Nomor 31 Tahun 1999 Tentang Pemberantasan Tindak Pidana Korupsi.

Sehingga kalau yang didakwakan Penuntut Umum itu terhadap Terdakwa selaku penerima uang adalah tindak pidana yang dengan maksud menguntungkan diri sendiri atau orang lain secara melawan hukum "memaksa" seseorang memberikan sesuatu, membayar atau menerima pembayaran dengan potongan atau untuk mengerjakan sesuatu bagi dirinya sendiri \{Pasal 12 huruf (e) (f) dan (g) Undang-Undang Republik Indonesia Nomor 20 Tahun 2001 Atas Perubahan Undang-Undang Republik Indonesia Nomor 31 Tahun 1999 Tentang Pemberantasan Tindak Pidana Korupsi\}, yang oleh hakim telah dinyatakan terbukti, lalu apakah Saksi selaku Pemberi Uang dapat ditetapkan menjadi Tersangka? Maka untuk menjawab pertanyaan ini harus dikaji dulu tentang unsur pertanggungjawaban pidananya.

Menurut Roeslan Saleh7 dalam bukunya "Pidana dan Pertanggungan Jawab Pidana" halaman 81, mengemukakan: "seseorang tidak dapat dipertanggungjawabkan dan dijatuhi pidana apabila tidak melakukan suatu tindak pidana, akan tetapi meskipun ia melakukan suatu tindak pidana tidaklah selalu ia dapat dipidana. Orang yang melakukan perbuatan pidana akan dipidana apabila ia mempunyai kesalahan".

Menurut D. Simons, sebagaimana dikutip oleh Roeslan Saleh ${ }^{8}$ dalam bukunya tersebut: "kesalahan adalah keadaan psikis orang yang melakukan perbuatan dan hubungannya dengan perbuatan yang dilakukan, yang sedemikian rupa, sehingga orang itu dapat dicela karena perbuatan tadi. Jadi yang harus diperhatikan adalah:

1. Keadaan batin dari orang yang melakukan perbuatan tadi,

Roeslan Saleh, Pidana dan Pertanggungan Jawab Pidana. Jakarta: Aksara Baru, 2010, hlm. 81.

8 Ibid., hlm. 82. 
2. Hubungan antara keadaan batin itu dengan perbuatan yang dilakukan sedemikian rupa, sehingga orang itu dapat dicela karena perbuatan tadi.

Dari dua hal yang harus diperhatikan itulah terjalin erat satu dengan lainnya, merupakan hal yang dinamakan kesalahan.

Menurut Memorie van Toelichting (MvT) ${ }^{9}$, maka kata "dengan sengaja" dalam pasalpasal KUHPidana adalah sama dengan "willens en wettens" (dikehendaki dan diketahui).

Berdasarkan uraian tersebut di atas dapat disimpulkan bahwa:

1. Pertanggungjawaban pidana selalu didasarkan pada adanya kesalahan (schuld). Kesalahan tersebut menunjuk kepada sikap batin (mens rea) tertentu dari Terdakwa dalam hubungannya dengan perbuatan pidana yang dilakukan sedemikian rupa sehingga Terdakwa dapat dicela karena melakukan perbuatan tersebut.

2. Dalam menilai ada atau tidaknya kesalahan Terdakwa tidaklah digantungkan pada sisi psikologis dari Terdakwa sendiri, akan tetapi didasarkan kepada bagaimana sikap batin tersebut tercermin dari perbuatan nyata dan kemudian dinilai oleh pihak lain, terutama oleh Majelis Hakim yang memeriksa dan mengadili perkara tersebut

Dalam kaitan "pertanggungjawaban pidana" tersebut apabila dihubungkan dengan perbuatan Saksi selaku yang telah memberikan uang kepada Terdakwa (selaku penerima uang) sebagaimana telah diuraikan di atas, maka tentu saja tidak cukup hanya dengan melihat atau memedomani 2 (dua) alat bukti itu saja, tetapi yang paling penting adalah harus dilihat dari aspek kesalahannya.

Apabila perbuatan Terdakwa (selaku penerima uang) dinyatakan telah terbukti melanggar Pasal 12 huruf (e) Undang-Undang Republik Indonesia Nomor 20 Tahun 2001 Atas Perubahan Undang-Undang Republik Indonesia Nomor 31 Tahun 1999 Tentang Pemberantasan Tindak Pidana Korupsi, maka penulis berpendapat bahwa Saksi selaku yang pihak yang telah memberikan uang kepada Terdakwa (pelaku pungli) tidak dapat ditetapkan menjadi Tersangka.

9 E. Utrecht, Rangkaian Sari Kuliah Hukum Pidana 1, Surabaya: Pustaka Tinta Mas, 1958, hlm. 292. 


\section{Penerapan Pasal 11 Undang-Undang Republik Indonesia Nomor 20 Tahun 2001 Atas Perubahan Undang-Undang Republik Indonesia Nomor 31 Tahun 1999 Tentang Pemberantasan Tindak Pidana Korupsi Terhadap Pelaku Pungutan Liar}

Pasal 11 Undang-Undang Republik Indonesia Nomor 20 Tahun 2001 Atas Perubahan UndangUndang Republik Indonesia Nomor 31 Tahun 1999 Tentang Pemberantasan Tindak Pidana Korupsi sering kali dijadikan sebagai dakwaan pelapis atau alternatif Kedua dari Pasal 12 huruf (e) Undang-Undang Republik Indonesia Nomor 20 Tahun 2001 Atas Perubahan UndangUndang Republik Indonesia Nomor 31 Tahun 1999 Tentang Pemberantasan Tindak Pidana Korupsi.

Pasal 11 dengan Pasal 12 itu subjeknya memang sama-sama pegawai negeri atau penyelenggara Negara, namun demikian terdapat perbedaan substansial dilihat dari aspek kesalahan dan pertanggungjawaban pidananya, Pasal 11 itu pendekatannya menerima hadiah atau janji padahal diketahui patut diduga bahwa hadiah atau janji tersebut diberikan karena kekuasaan atau kewenangan yang berhubungan dengan jabatannya atau yang menurut pikiran orang yang memberikan hadiah atau janji tersebut ada hubungan dengan jabatan si penerima, kata hadiah atau janji menunjukkan ada 2 (dua) pihak yang menghendakinya maka dapat disimpulkan bahwa dalam Pasal 11 ada deal kesepakatan, sehingga Pasal 11 adalah merupakan pasal delik suap menyuap dan merupakan pasal yang berpasangan, jika penerima hadiah diancam dengan Pasal 11 maka pemberinya diancam dengan Pasal 13 Undang-undang Tipikor. Berbeda dengan Pasal 12 huruf (e) dimana terdapat posisi yang lebih dominan selaku penerima uang sebagai pegawai negeri atau penyelenggaraan negara yang mempunyai kekuasaan atau kewenangan yang digunakan untuk memaksa pihak yang lain untuk memberikan sesuatu, membayar atau menerima pembayaran dengan potongan atau dengan mengerjakan sesuatu bagi dirinya sendiri, sehingga kalau unsur paksaan atau memaksa tidak terpenuhi maka delik tersebut bukan Pungutan Liar (Pungli).

Ada 3 (tiga) unsur yang terkandung dalam Pasal 11 Undang-Undang Republik Indonesia Nomor 20 Tahun 2001 Atas Perubahan Undang-Undang Republik Indonesia Nomor 31 Tahun 1999 Tentang Pemberantasan Tindak Pidana Korupsi, yaitu:

1. Pegawai negeri atau penyelenggara Negara;

2. Menerima hadiah atau janji;

3. Padahal diketahui atau patut diduga bahwa hadiah atau janji tersebut diberikan karena kekuasaan atau kewenangan yang berhubungan dengan jabatannya atau 
yang menurut pikiran orang yang memberikan hadiah atau janji tersebut ada hubungan dengan jabatannya.

Seseorang yang didakwa melakukan tindak pidana harus memenuhi semua unsur pidana yang disangkakan untuk dijatuhi pidana dan harus ada suatu kesalahan serta tidak boleh ada alasan pembenar atau alasan pemaaf, sedangkan orang yang dapat dimintai pertanggungjawaban pidana syaratnya 1) orang tersebut secara bebas bisa menentukan kehendaknya dan merefleksikan dan melaksanakan kehendaknya itu secara bebas, 2) orang tersebut memiliki keadaan jiwa yang mampu menilai dan mengerti tentang nilai-nilai perbuatan yang akan dilakukan itu buruk atau tidak buruk dan 3) dapat menilai apa yang akan terjadi sebagai akibat perbuatannya itu.

Oleh karena subjek Pasal 12 Huruf (e) dengan Pasal 11 adalah sama-sama pegawai negeri atau penyelenggara Negara, maka dalam surat dakwaan kedua Pasal tersebut boleh diajukan sekaligus dengan bentuk surat dakwaan alternatif (pilihan), namun untuk membuktikan dan membedakan pasal mana yang terbukti haruslah dilihat unsur subjektifnya yaitu dengan melihat sikap batinnya. Dalam Pasal 11 unsur subjektif atau sikap batinnya yaitu pengetahuan (sengaja), culpa (patut menduga) dan yang ketiga yaitu mengetahui atau menduga menurut pikiran orang yang memberi hadiah atau janji tersebut ada hubungannya dengan jabatan penerima dan unsur batin ini tidak hanya pada penerima melainkan juga ada pada si pemberi karena niat si pemberi tidak terlepas dari memberi sesuatu untuk berharap sesuatu jadi ada hubungan timbal balik. Berbeda dengan pasal 12 huruf (e), dimana unsur batinnya hanya ada pada si penerima saja yang lebih dominan dengan memanfaatkan kekuasaan atau kewenangannya untuk memaksa orang lain memberikan sesuatu kepadanya, sehingga orang lain itu memberi bukan karena menghendaki melainkan karena terpaksa.

Maka dengan demikian, Pasal 11 Undang-Undang Republik Indonesia Nomor 20 Tahun 2001 Atas Perubahan Undang-Undang Republik Indonesia Nomor 31 Tahun 1999 Tentang Pemberantasan Tindak Pidana Korupsi dalam kasus Pungutan Liar (Pungli) sebagai Tindak Pidana Korupsi tidak dapat diterapkan, karena yang dikategorikan sebagai pungutan liar hanya yang memenuhi unsur "memaksa seseorang memberikan sesuatu, membayar atau menerima pembayaran dengan potongan atau untuk mengerjakan sesuatu bagi dirinya sendiri" yang menjadi unsur utama dari Pasal 12 huruf (e) Undang-Undang Republik Indonesia Nomor 20 Tahun 2001 Atas Perubahan Undang-Undang Republik Indonesia Nomor 31 Tahun 1999 Tentang Pemberantasan Tindak Pidana Korupsi. 


\section{KESIMPULAN}

1. Saksi selaku pemberi uang dalam kasus Pungutan Liar (Pungli) sebagai Tindak Pidana Korupsi secara hukum tidak dapat ditetapkan menjadi Tersangka memberi suap atau hadiah, karena saksi yang memberikan uang tersebut tidak mempunyai "niat jahat atau mens rea", sehingga Saksi yang memberikan uang tersebut kepada si Tersangka/Terdakwa adalah merupakan korban. Unsur "Memaksa orang untuk memberikan sesuatu, membayar atau menerima pembayaran dengan potongan atau dengan mengerjakan sesuatu bagi dirinya sendiri" adalah merupakan syarat mutlak yang harus dipenuhi dalam delik korupsi dengan modus Pungutan liar (Pungli), apabila Unsur "memaksa" tersebut tidak dapat dibuktikan sekalipun unsur-unsur yang lainnya terpenuhi, maka perbuatan Tersangka/Terdakwa tersebut bukan merupakan perbuatan Pungutan Liar (Pungli) sebagaimana dimaksud dalam Pasal 12 huruf (e) Undang-Undang Republik Indonesia Nomor 20 Tahun 2001 Atas Perubahan Undang-Undang Republik Indonesia Nomor 31 Tahun 1999 Tentang Pemberantasan Tindak Pidana Korupsi.

2. Pasal 11 Undang-Undang Republik Indonesia Nomor 20 Tahun 2001 Atas Perubahan Undang-Undang Republik Indonesia Nomor 31 Tahun 1999 Tentang Pemberantasan Tindak Pidana Korupsi, tidak dapat diterapkan pada kasus korupsi dengan modus Pungutan Liar (Pungli), karena pada hakikatnya Pasal 11 UndangUndang Republik Indonesia Nomor 20 Tahun 2001 Atas Perubahan UndangUndang Republik Indonesia Nomor 31 Tahun 1999 Tentang Pemberantasan Tindak Pidana Korupsi adalah pasal yang berpasangan yang digunakan untuk delik suap menyuap. Sehingga apabila dalam persidangan Penuntut Umum mengajukan tuntutan terhadap Terdakwa melanggar Pasal 11 Undang-Undang Republik Indonesia Nomor 20 Tahun 2001 Atas Perubahan Undang-Undang Republik Indonesia Nomor 31 Tahun 1999 Tentang Pemberantasan Tindak Pidana Korupsi, maka Saksi selaku Pemberi Uang haruslah ditarik dan ditetapkan menjadi Tersangka memberi suap atau memberi hadiah.

\section{Daftar Pustaka}

\section{Buku}

Chazawi, Adami, Hukum Pidana Materiil dan Formil di Indonesia, Edisi Pertama, Cetakan Kedua, Malang: Bayu Media Publishing, 2005. 
Harahap, M. Yahya, Pembahasan, Permasalahan dan Penerapan KUHAP, Jakarta: Pustaka Kartini, 1993.

Kartanegara, Satochid, Hukum Pidana Bagian Satu, Jakarta: Balai Lektur Mahasiswa, 2007. Marzuki, Peter Mahmud, Penelitian Hukum Edisi Revisi, Cet. VII, Jakarta: Prenada Media Group, 2011.

Saleh, Roeslan, Pidana dan Pertanggungan Jawab Pidana. Jakarta: Aksara Baru, 2010.

Soesilo, R., Pokok-Pokok Hukum Pidana Peraturan Umum dan Delik-delik Khusus, Bogor: Politea, 1984.

Utrecht, E., Rangkaian Sari Kuliah Hukum Pidana 1, Surabaya: Pustaka Tinta Mas, 1958.

\section{Jurnal}

Wibawa, Samodra, Arya Fauzy F.M, dan Ainun Habibah, "Efektivitas Pengawasan Pungutan Liar Di Jembatan Timbang,". Jurnal Ilmu Administrasi Negara, Vol 12 No 2, Januari 2013.

\section{Peraturan Perundang-undangan}

Undang-Undang Nomor 1 Tahun 1946 Tentang Peraturan Hukum Pidana Undang-Undang Nomor 73 Tahun 1958 Tentang Menyatakan Berlakunya Undang-Undang No.

1 Tahun 1946 Republik Indonesia Tentang Peraturan Hukum Pidana Untuk Seluruh

Wilayah Republik Indonesia dan Mengubah Kitab Undang-Undang Hukum Pidana, (Lembaran Negara Republik Indonesia Tahun 1958 Nomor 127, Tambahan Lembaran Negara Republik Indonesia Nomor 1660).

Undang-Undang Republik Indonesia Nomor 8 Tahun 1981 Tentang Hukum Acara Pidana,

(Lembaran Negara Republik Indonesia Tahun 1981 Nomor 76, Tambahan Lembaran Negara Republik Indonesia Nomor 3209).

Undang-Undang Republik Indonesia Nomor 31 Tahun 1999 Tentang Pemberantasan Tindak Pidana Korupsi, (Lembaran Negara Republik Indonesia Tahun 1999 Nomor 140, Tambahan Lembaran Negara Republik Indonesia Nomor 387).

Undang-Undang Republik Indonesia Nomor 20 Tahun 2001 Tentang Perubahan atas UndangUndang Republik Indonesia Nomor 31 Tahun 1999 Tentang Pemberantasan Tindak Pidana Korupsi, (Lembaran Negara Republik Indonesia Tahun 2001 Nomor 134, Tambahan Lembaran Negara Republik Indonesia Nomor 4150). 
Undang-Undang Republik Indonesia Nomor 46 Tahun 2009 Tentang Pengadilan Tindak Pidana Korupsi, (Lembaran Negara Republik Indonesia Tahun 2009 Nomor 155, Tambahan Lembaran Negara Republik Indonesia Nomor 5074).

Undang-Undang Republik Indonesia Nomor 48 Tahun 2009 Tentang Kekuasaan Kehakiman, (Lembaran Negara Republik Indonesia Tahun 2009 Nomor 157, Tambahan Lembaran Negara Republik Indonesia Nomor 5076).

Peraturan Presiden Republik Indonesia Nomor 87 Tahun 2016 Tentang Satuan Tugas Sapu Bersih Pungutan Liar, (Lembaran Negara Republik Indonesia Tahun 2016 Nomor 202). 